\title{
TOPICS TOPICS TOPICS TOPICS TOPICS TOPICS TOPICS TOPICS TOPICS TOPICS
}

\section{Sildenafil と肺高血圧}

\section{浜松医科大学臨床薬理学}

渡邊裕司

はじめに

Sildenafil（商品名バイアグラ®）は，英国ファイザー 研究所で抗狭心症薬を開発中に, 勃起症状を副作用として 持つ薬剤として発見された。 その後, 臨床試験を経て勃起 不全治療薬として米国 FDA ょり認可され，わが国では 1999 年 3 月から自由診療の薬剤として発売が開始されて いる。しかし, sildenafilのターゲットとなるホスホジエ ステラーゼ 5 型（PDE5）は陰茎血管以外に肺血管にも多 く分布しており ${ }^{1)}$, sildenafil 投与が勃起不全のみでなく, 肺高血圧症にも極めて有効であることが近年注目されるよ うになった ${ }^{2,3)}$. 我々も肺高血圧症に対する sildenafil 治療 の有効性について検討を行い, すでに数症例には 2 年以上 sildenafil を継続投与し長期の改善効果を認めている。本 稿では，肺高血圧症に対する sildenafil の作用について， 我々の成績をまじえ紹介する。

\section{肺高血圧症とこれまでの治療}

肺高血圧症は，原発性肺高血圧症と先天性心疾患や膠原 病などの先行する疾患によって二次的に生じる二次性肺高 血圧症に大別される，いずれの場合にも，労作時の息切れ や動悸，突然の失神発作や右心不全徵候である顔面や下腿 の浮腫などの症状により，患者の生活の質は著しく低下す る。原発性肺高血圧症は，人口 100 万人当りおよそ 1 人か ら 2 人の割合で発症する極めてまれな疾患だが，30 歳前 後の比較的若い世代の発症例が多く，確定診断後の平均生 存期間は約 3 年と生命予後が極めて不良な疾患として知ら れている。膠原病に合併する二次性肺高血圧症は女性に多 く, 原発性肺高血圧症と類似した経過をとり, 膠原病患者 の予後を規定する合併症である。

肺高血圧症の治療として，カルシウム拮抗薬の内服，一 酸化窒素 (NO) の吸入，プロスタサイクリン製剤の内服 や持続静注などの内科的治療，内科的治療に抵抗性の症例 に対しては外科的に肺移植が行われている，近年，プロス タサイクリン製剤の有効性が広く認められ，治療成績も向 上してきているが，その持続静注療法は静注ルートからの 感染を予防し，適確な注入量を保持し，小型注入ポンプを 常時携帯することなどの細かな配虑が必要とされる．また 薬剤費も高額であり，医療経済的な問題も生じている。カ

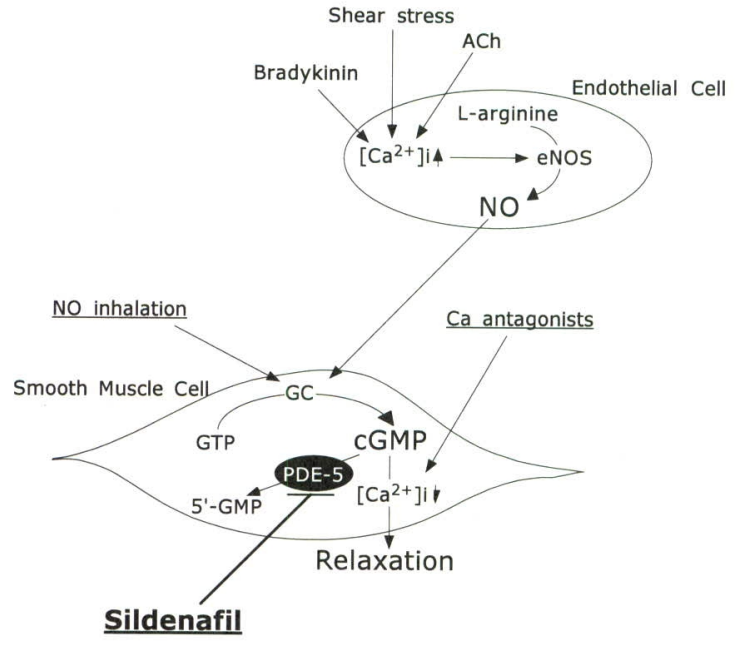

Fig. 1 Sildenafil の作用機序

ルシウム拮抗薬は，肺血管への選択性が低く肺動脈圧とと もに全身血圧を低下させてしまい，わが国での有効例は少 ない．このような背景から，経口投与可能で，全身血圧を 低下させずに肺動脈圧のみを選択的に低下させるような薬 物が待ち望まれてきた。

\section{Sildenafil の作用機序と肺高血圧症治療への応用}

原発性肺高血圧症の発症要因の 1 つとして, 肺血管内皮 細胞の NO 産生能の低下など, NO-cGMP 系のシグナル 伝達の異常が指摘されている。NO において産生され，血管平滑筋細胞に作用し，グアニル酸 シクラーゼを活性化して GTP ょり cGMP を生成する。 cGMP は細胞内 $\mathrm{Ca}^{2+}$ 濃度を低下させ，平滑筋細胞を弛緩 させ血管拡張をもたらす。しかし，cGMP は PDE5 によ り $5^{\prime} \mathrm{GMP}$ へと速やかに分解されてしまい，その効果は持 続しない. NO 吸入療法は，吸入を中断すると速やかに肺 動脈圧が上昇し，症状の急激な悪化をもたらすリバウンド 現象を生じる欠点を持つ。その原因は，NO が短寿命であ り，NOにより生成された CGMPもまた PDE5 の働きに より速やかに分解されてしまうためである. Sildenafil は この PDE5 を阻害することにより，cGMPの分解を抑制 乙血管拡張をもたらすが (Fig. 1)，陰茎血管以外に肺血 管にも PDE5 が豊富に存在することが明らかにされ，肺 高血圧症治療への応用が考元られるようになった。1999 年に sildenafil が NO 吸入治療中断時の肺血圧上昇を抑制 することが初めて報告され゙), さらに翌年「 $\mathrm{N}$ Engl J Med」に 21 歳の原発性肺高血圧症患者の自覚症状と運動 耐容能が sildenafil 投与により著明に改善したことが報 告3)されて以来， sildenafil の肺高血圧症に対する有効性 を示唆する報告が急激に増加している。 


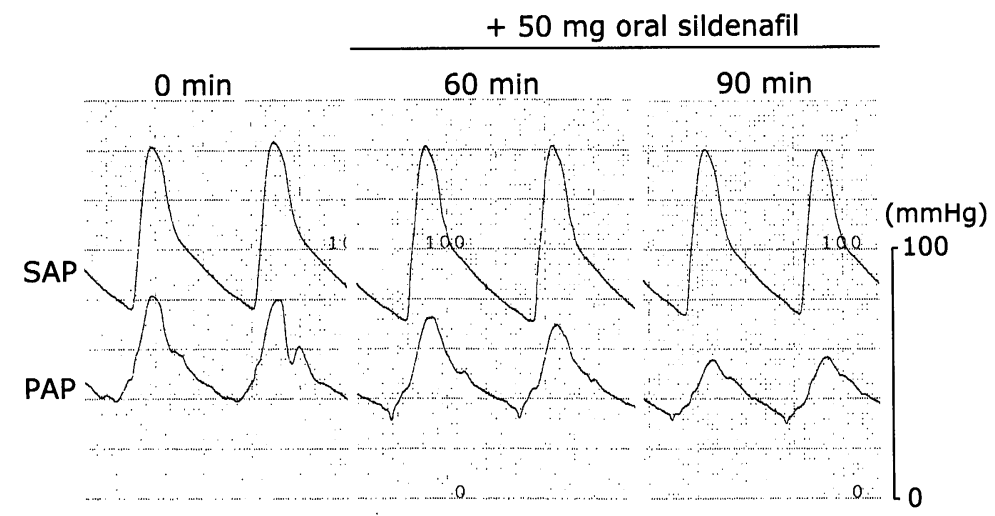

Fig.2 原発性肺高血圧症例における sildenafil の急性効果 （文献 5)より引用）

\section{Sildenafil の有効性}

我々は，2001 年 2 月より浜松医科大学倫理委員会の承 認の下，文書同意が得られた原発性肺高血圧症 2 例，膠原 病に合併する肺高血圧症 5 例, 先天性心疾患に合併した 3 例の計 10 例（男性 3 例，女性 7 例，平均年齢 39 歳）に sildenafil を投与し, 先天性心疾患に合併した 3 例を除く 7 例で急性効果を認めている. Fig. 2 は，40 歳の女性の原 発性肺高血圧症例における sildenafil の急性効果を示した もので, sildenafil 投与 90 分後に肺動脈収縮期圧は 80 か ら $57 \mathrm{mmHg}$, 拡張期圧は 38 から $31 \mathrm{mmHg}$ ，平均 圧は 54 から $40 \mathrm{mmHg}$ へと低下した。一方，sildenafil 投 与後も大動脈圧には有意な変化を認めず，心拍出量は 15\%増加，肺血管抵抗は 39\%低下している。本症例はそ の後 sildenafil の長期投与を開始し，短期間のうちに自覚 症状の著明な改善を認めた5).

7 例の反応例では, sildenafil $(50 \mathrm{mg})$ の経口投与によ り，それぞれ平均值で肺動脈平均圧は $27 \%$ 低下，心拍出 量は $16 \%$ 増加，結果として肺血管抵抗は $40 \%$ 低下してい る.一方，全身血圧には変化を認めず，極めて肺選択性が 高い薬物であることが明らかとなった，反応例には 3 力月 間の長期投与（sildenafil $25 \mathrm{mg}$ を 1 日 2 回経口投与）を 行い, 自覚症状と運動耐容能の有意な改善と, BNP 值の 半減を認めた。 また 3 カ月後の再度の心臓カテーテル検査 により，初回検査時と同様の急性効果が保たれていること が確認された。軽度の顔のほてり以外には副作用も認め ず，臨床検查值の異常も認められなかった。一方，先天性 心疾患合併例では無効だった原因として，シャント性疾患 という病態，また肺高血圧症を発症してからの期間が原発 性肺高血圧症や膠原病合併例では $2 \sim 3$ 年であるのに対し， 先天性心疾患合併例は 10 年以上経過していることなどの 罹病期間の差が影響しているのではないかと考えている. 最近, sildenafil が慢性血栓塞栓性肺高血圧症苜や肺線
維症に伴う肺高血圧症》にも有効であることが報告され， プロスタサイクリン製剤不応例に対しても有効である可能 性が示唆されている。

\section{今後の展望}

肺高血圧症治療薬の理想的条件として，体血圧を低下さ せずに肺動脈圧を $25 \%$ 低下させ，肺血管抵抗を $33 \%$ 以上 低下させることが挙げられているが, sildenafil はこの条 件を満たす治療薬であることが示唆される，急性効果が認 められる薬物によって, 肺高血圧症患者の長期予後は一般 に改善することが示されており， sildenafil に対する期待 は大きい.しかし，製薬企業は肺高血圧症のような稀少疾 患に対しての適応拡大に必ずしも積極的ではない.このよ うな場合にこそ，医師主導の臨床試験が組織され， sildenafil の有効性をさらに検証することが必要であるとと もに, 他の PDE5 阻害薬の有用性の検討や長時間作用型 製剤の開発も重要な課題と思われる。

\section{文献}

1) Rabe $\mathrm{KF}$, et al. Identification of $\mathrm{PDE}$ isozymes in human pulmonary artery and effect of selective PDE inhibitors. Am J Physiol 1994 ; 266 : L536-43.

2) Lodato RF. Viagra for impotence of pulmonary vasodilator therapy? Am J Respir Crit Care Med 1998; 158:1388-95.

3) Prasad S, et al. Sildenafil in primary pulmonary hypertension. $N$ Engl J Med $2000 ; 343: 1342$.

4) Atz AM, et al. Sildenafil ameliorates effects of inhaled nitric oxide withdrawal. Anesthesiology $1999 ; 91$ : 307-10.

5) Watanabe $\mathrm{H}$, et al. Sildenafil for primary and secondary pulmonary hypertension. Clin Pharmcol Ther 2002; 71: 398-402.

6) Ghofrani HA, et al. Sildenafil for long-term treatment of nonoperable chronic thromboembolic pulmonary hypertension. Am J Respir Crit Care Med 2003; 167:1139-41.

7) Kleinsasser A, et al. Sildenafil for lung fibrosis and pulmonary hypertension. Lancet $2002 ; 360: 262-3$. 